\title{
"Bannabees," Bananas, and Sweet Potatoes: Claude McKay's Songs of Jamaica and Traditional Jamaican Foodways as a Nationalist Expression
}

\author{
*Sarah Hovet, English and Journalism
}

\begin{abstract}
Jamaican poet Claude McKay is largely anthologized for a handful of poems he contributed to the Harlem Renaissance, but his early work authored in Jamaica has long been dismissed for a variety of racist and xenophobic reasons. This overlooked material includes his first two poetry collections, Songs of Jamaica and Constab Ballads, both authored in Jamaica before he moved to New York. His friend, benefactor, and mentor Walter Jekyll even characterized these early collections as "naive." However, these two collections, which mix traditional English forms with Jamaican peasant dialect, constitute vital parts of McKay's oeuvre. Songs of Jamaica in particular exhibits a mastery of Jamaican peasant dialect in combination with extensive allusions to traditional folkways in order to make an anti-colonialist, nationalist assertion about Jamaica, the country McKay so loved. I will analyze the role of Jamaican peasant dialect and foodways in making this nationalist assertion in order to advance my claim that McKay's early poetry is at least as sophisticated and versatile as his subsequent collections authored in the States. By turns, McKay praises native Jamaican crops such as the banana, sweet potato, and Bonavist bean for their gustatory, nutritional, and economic superiority to crops imported by colonialism.
\end{abstract}

Jamaican poet Claude McKay is most commonly known as a prominent figure in the Harlem Renaissance, with the rather unfortunate effect that his diverse oeuvre has been reduced to his 1919 sonnet "If We Must Die," which protests the social inequality of black people in America. He penned this poem after he moved from Jamaica to New York. In light of this poem and his collection Harlem Shadows, critics often consider his poetry produced in America as the beginning of his serious writing career. They tend to dismiss his two previous poetry collections, Songs of Jamaica and Constab Ballads, both authored in Jamaica, as immature works. Even his friend, benefactor, and mentor Walter Jekyll characterized Songs of Jamaica as stylistically "naive" in his introduction to the volume (McKay 284). However, these two collections, which mix

* Sarah Hovet is a senior pursuing English and journalism majors and a creative writing minor in the Robert D. Clark Honors College. She is currently applying to master's degree programs in English literature and working on her honors thesis. Her research interests include feminism and gender in modern Welsh and Irish literature and syntax in contemporary American poetry, among other diverse topics. Please direct correspondence to shovet@uoregon.edu. 
traditional English forms with Jamaican peasant dialect, constitute vital parts of McKay's oeuvre. Songs of Jamaica exhibits a mastery of Jamaican peasant dialect in combination with extensive allusions to Jamaican folk culture in order to make an anti-colonialist, nationalist assertion about Jamaica, the country McKay so loved. In particular, the role of Jamaican peasant foodways in Songs of Jamaica makes a nationalist assertion that advances the claim that McKay's early poetry is at least as sophisticated as and more versatile than his subsequent collections authored in the States. Foodways serve as a subtle, credible way for McKay to center indigenous ways of knowing and non-colonial crops as superior.

In comparison to "If We Must Die," which is widely anthologized, McKay's Jamaican poetry remains overlooked. Decades later, McKay scholars continue to mischaracterize the Jamaican poems as "sentimental," even as "genre studies" of peasant life (Hansell 123). In fact, William Hansell divides the Jamaican poetry into three categories: slice-of-life commonplace, love poems, and poems that "portray the peasant mind," in his words (124-125). Such categorizations come across as reductive and condescending, collapsing the political dimensions of the early poetry. After all, McKay's Jamaican years remain understudied and poorly understood, obscuring their significance to his artistic oeuvre (James, "Becoming the People's Poet" 19). Due to both these misperceptions represented by Hansell and the lack of sustained academic inquiry described by James, the subtle, sophisticated poetic style and the emphatically nationalist content of Songs of Jamaica have been downplayed in most existing scholarship. But McKay's support of the black oppressed and his trenchant critique of racist social structures emerges in Songs of Jamaica through various expressions of anti-colonialist nationalism, such as his focus on native crops.

Due to a variety of social constraints, McKay's anti-colonial nationalism in his early poetry often proves measured and subtle. For instance, McKay's 1912 poem "De Gubnor's Salary" critiques Sir Sydney Olivier for taxing the Jamaican people in order to pay his salary, despite the fact that the English rule Olivier represented had accomplished nothing but the oppression of the Jamaican people (Rosenberg 94). McKay agreed to leave the poem out of Songs of Jamaica and Constab Ballads, as Olivier demanded. He even dedicated the former volume to the governor, who was also his benefactor. His poetry often constituted "acts of dexterity" within a system in which "oppositional views could be expressed primarily from within colonial institutions" (Rosenberg 93-94). However, his selection of the Jamaican crops that represent traditional foodways in Songs of Jamaica, such as the Bonavist bean, the sweet potato, or the banana, bespeak an anti-colonialist nationalism he could not explicitly include in his poems at the time while living in Jamaica.

The most prominent example of McKay's nationalism in his early poetry manifests in his constant use of Jamaican peasant dialect. This tactic negotiates thickets of politics around the use of dialect in writing, with various critics decrying McKay as racist for the thick Jamaican peasant dialect in which he wrote his first two collections. As Jamaican magazines and newspapers opened the subject for discussion, the controversy heightened given the cultural moment, one which "presented Jamaica as progressing toward enlightenment and morality" (Rosenberg 40). The Jamaican Local Literary Association published an anonymous 1913 essay "On Dialect" that championed the use of Jamaican dialect in literature, arguing, "Dialect tells the story of 
colonisation, of slavery and its villainies, of the Emancipation won for the downtrodden negro" (Rosenberg 40). The article even goes so far as to suggest, "Had we a Claude McKay, one genius at least, for every decade since 1800 ... the pride of Jamaica in things Jamaican would today be a fixed quantity" (Rosenberg 40). An inquiry into the possibility of McKay himself penning this eloquent missive, given his penchant for reputation-burnishing, might prove interesting. Regardless, the nationalist potential of McKay's use of dialect serves as a way of proposing a linguistic distinctiveness and unity, rich with a history of struggle and perseverance under colonization. Conversely, other critics, such as the lawyer and writer James Weldon Johnson, argued that "acting modern meant not writing or speaking 'too black' because African-American dialect had been so tarred and tarnished by its historical associations with minstrelsy and racism" (Peppis 38). And thus McKay found himself navigating cultural and literary critics in addition to the colonial institutions in which he lived, complicating yet another intended anti-colonialist nationalist assertion.

Given the complexities surrounding these expressions of McKay's nationalism, his use of traditional Jamaican foodways in Songs of Jamaica emerges as a means of making an anticolonialist, pro-Jamaican claim that centers his authority. Thomas Francis and Ann Elizabeth McKay brought up McKay, the former being a farmer who "coaxed" cacao, coffee, bananas, sugar cane, and tropical fruits from the "difficult soil" of the country; thus, McKay grew up acquainted with farming and Jamaican foodways (Tillery 4). Upon arriving in the United States, he even intended to study agronomy at the Tuskegee Institute in South Carolina (21). McKay's love for the island originated in part from his image of its soil as containing plentitude for all of its black inhabitants (James, "Jamaican Nationalism and Its Limits" 91). As McKay stipulates in "My Native Land, My Home" from Songs of Jamaica, "De time when I'll tu'n 'gains' you is/When you can't give me grub" (Complete Poems, 58). Therefore, McKay possesses an intimate knowledge of Jamaican agriculture, its hardships and its rewards, and links the bounty of the land to a conditional nationalism, making peasant foodways inextricable to any nationalist assertion he would level in his collections of Jamaican dialect poetry.

For example, in the poem "Me Bannabees" from Songs of Jamaica, McKay elevates traditional folk foodways through the speaker's celebration of bannabees, or the Bonavist bean. He clearly demonstrates this celebration when he concludes the poem with the preferential declaration "Caan' talk about gungu,/Fe me it is no peas;/Cockstone might do fe you,/Me want me bannabees," which carries additional weight as the final stanza in the poem (20). The stanza juxtaposes "gungu" and "cockstone," or Congo peas and red kidney beans, with the bannabees -the other legumes might do for others, but not for the speaker, who wants his bannabees. Likewise, in the opening stanza, the bannabees "Run ober mango trees," suggesting that the bannabees are more desirable than lush mangos, with the bannabees hierarchically positioned over them. Tellingly, "bannabees" is assonant with "want" and "wanna," underscoring the speaker's desire for the bannabees, the traditional Jamaican crop. Thus, the bannabees represent the superiority of Jamaican folk culture and foodways, which the speaker can appreciate above all else, but colonial outsiders cannot. 
Cross-referencing McKay's selected crops with other works on Jamaican culture and agriculture demonstrates the deliberate choices McKay made of non-colonial crops with particular cultural connotations, such as sweet potatoes and bananas. In his 2008 book Jamaican Food: History, Biology, Culture, Jamaican studies scholar B. W. Higman traces the histories of various Jamaican crops, illuminating their cultural connotations at the time of McKay's writing. Higman writes, "Relating the colourfully descriptive common names [of all the beans] to the correct scientific names is often a puzzle" (254). He does provide enriching details on the Bonavist bean, which "[flourishes] all year," reinforcing the image of its lush growth over the mangos in "Me Bannabees" (256). Furthermore, he claims that bannabees are "cultivated by most of the inhabitants in the country parts of Jamaica," associating the crop not only with Jamaican national identity, but specifically with rural Jamaican national identity, the peasant farmer class with whom McKay aligned himself in his early work (256). Interestingly, Higman's entry on bannabees cites McKay's poem itself as "[extolling the bean's] virtues," alongside the Jamaican proverb "Time neber too long fe the Bannabis bear bean" (257). Therefore, McKay's usage of traditional Jamaican foodways in his early poetry has been noted by scholars of Jamaican foodways, bolstering its credibility as a prevalent theme and nationalist claim.

"Me Bannabees" proudly proclaims the superiority of the bannabees over Congo peas and kidney beans, implying the speaker's affinity with the beans is at the exclusion of a colonial outsider. At the same time, it does not engage in explicit racial claims, unlike the poem "Quashie to Buccra." The title positions two individuals identified by racial group in dialogue with each other, the "quashie," or black man, addressing the "buccra," or white man. Caroline Sullivan's 1893 Jamaica Cookery Book records the process of cassava being made into wafer-like "lace cakes," which were commercially marketed in the 1950s as "bammy chips, thin as paper -- not made by Quashie" (Higman 67). Therefore, race played a role in conceptions of the quality of crops, dishes, and cooking processes, if the fact the cassava cakes were not made by Quashie, or a black man, was considered a selling point. However, in "Quashie to Buccra," the Quashie speaker addresses the white man in order to assert not only that his methods of growing "petaters" is superior, but that the Quashie, or laboring class, has developed a more acute palate for the potatoes through maintaining them than the Buccra could ever understand.

In "Quashie to Buccra," the speaker describes the myriad hardships of working the soil to produce sweet potatoes, which elevates his enjoyment of the crop's ultimate reward, as a way to exalt the Jamaican farmer class. "De fiel' pretty? It couldn't less 'an dat," the speaker jeers, mocking the presumed Buccra for admiring the field's clean appearance and even lines, when its beauty is an incidental byproduct of the hard labor that goes into maintaining it. McKay's lines perfectly mirror the sentiment that Jamaicans' attachment to their fields "was not only spiritual; the grounds were also containers of stored resources, long-term investments of labor and time" (Higman 60). Therein, the sweet potato fields house value that the Buccra, the colonial outsiders, cannot decipher. Throughout the poem, the speaker juxtaposes monetary value with toil's physical and psychological value: "You want a basketful fe quattiewut,/ 'Cause you no know how 'tiff de bush fe cut," in which the Buccra only thinks of the sixpence he can earn from selling the crop, rather than the labor that produced the crop. Thus, the colonizer lacks the capacity to appreciate 
the crop's true sweetness, which the Quashie savors "Wheneber it come roun' to reapin' day." McKay advocates the peasant Quashie's way of knowing over the colonial Buccra's limited perception.

In addition to the sweet potato's significance as an embodiment of peasant labor and ways of knowing, it retains a special status as a native plant with particular nutritional and symbolic value in Jamaica. The collection's footnotes define the "petater" in "Quashie to Buccra" as sweet potato, befitting the claim that in Jamaica "the generic potato is the sweet potato," while what Americans think of as a generic potato is referred to as the "Irish potato" (Higman 87). The sweet potato confers further cultural significance in light of the fact that Jamaicans often used the word "food" to specifically refer to starchy carbohydrates (Higman 55). This food also gained the designation of "ground provisions," which denotes "locally produced" Jamaican crops such as yam, coco, cassava, banana, plantain, and potato in contrast to "mostly imported" starchy crops such as wheat, corn, and rice (Higman 56). Therefore, potatoes embody a true Jamaican character, rather than a crop introduced by colonists. After all, Peter Martyr, who served as Abbot of Jamaica and guided construction of the first stone church on the island, recorded eight varieties of "patatas" in Jamaica prior to 1520 , confirming that "no doubt the species was indigenous to the island", and not a colonial transmission (Higman 88). As a native plant and cornerstone provision, the sweet potato proves itself a vehicle for a nationalist celebration, no doubt deliberately selected by McKay.

Likewise, "King Banana" reproduces this dialogue with a colonial Buccra and makes more explicit the gaps in colonial knowledge. "Wha' lef' fe buccra teach again/Dis time about plantation?/Dere's not'in that can beat de plain/Good ole-time cultibation" the speaker posits that the buccra has nothing left to teach the cultivators, presumably Quashies. "Plantation" denotes the act of planting in the poem, about which the white man has nothing to teach the black man, while also alluding to Jamaica's colonial history of sugar plantations in which white men dominated black men. The colonists lack the knowledge of "good ole-time cultibation," which is the province of the Quashie. Unlike the speaker in "Quashie to Buccra," the speaker in "King Banana" concerns himself with the banana's monetary value as well, peddling them in the marketplace: "We re'ch: banana finish sell," after which "Some hab money in t'read-bag well,/Some spen' all in a rum." However, McKay constructs the banana's economic value differently than the Buccra figure in the previous poem. The speaker seems more concerned with the rhythms of life( arriving in a group at the marketplace, spending the money earned on rum) which serves as a sort of glue to relationships in McKay's other works, such as Banjo. Finally, the poem culminates in an unequivocally nationalist assertion that the banana "mek" the black man, that the banana is absolutely conflated with Jamaica's national identity as "banana lan'," and that the banana "car' de sway," both economically and culturally.

Like the sweet potato, the banana was not a colonial transmission to Jamaica, although it remained less popular than the plantain into the late nineteenth century. In addition to the factor of the plantain being edible at all stages of ripeness, whereas the banana typically is only edible in its ripe form, only a limited selection of types of banana were available before the abolition of slavery in Jamaica. The Gros Michel variety from Martinique was not introduced to Jamaica until 
after abolition. It is also known as "green mancha” of "King Banana," the title of McKay's 1912 poem. Despite its prior obscurity, the banana rose as a new and profitable export crop for the island, rejuvenating the "languishing export economy" of the 1870s (Higman 140). On top of becoming a valuable trade commodity, the banana simultaneously adopted a new status domestically as a staple in the Jamaican diet. Higman's entry on the banana cites McKay's "King Banana" as an example of the "newfound enthusiasm" the banana enjoyed after its renewed importance in Jamaica's market (141). Additionally, its role in Jamaica's market underscores McKay's inclusion of a marketplace setting in “King Banana.” Once again, Higman's text mutually reinforces McKay's contributions to the culture around various Jamaican crops, and those crops' significance in McKay's work.

Ultimately, McKay's Jamaican dialect poetry deserves more scholarly attention than it has received, given the complexity and subtlety of his nationalism in these texts. McKay is forced to navigate the colonial institutions of his home. He even negotiates his own role in these institutions, such as the constabulary, yet finds ways to assert an anti-colonialist stance. His employment of Jamaican dialect served this purpose, but fell prey to controversy due to conflicting attitudes about dialect usage, i.e. whether dialect celebrated Jamaican history and unity, or paraded a caricature for a white colonial gaze that wanted to exoticize its speakers. However, McKay utilizes his knowledge of Jamaican foods and foodways to build an anticolonialist case. He centers peasant foodways as a superior way of knowing to the white colonists' commodification of the crops that the Jamaican peasant class has lovingly cared for and grown. He selects crops that do not possess a solely colonial history, such as the indigenous sweet potato, the banana introduced alongside the plantain before the arrival of Europeans, and the Bonavist bean of African origins. Furthermore, he conflates these crops with Jamaican identity, championing their gastronomic, nutritional, and economic worth above crops introduced by colonists, such as the mango. In this way, McKay centers non-colonial fruits, beans, and roots in order to cement a Jamaican superiority, one that extends to the black rural peasant class's ways of knowing that give them the ability to work the land and enhance their enjoyment of its fruits, a subtle and deft poetic maneuver that calls for scholars to recharacterize McKay's early dialect poetry.

\section{ACKNOWLEDGMENTS}

I would like to thank my faculty sponsor, Corbett Upton, for his feedback on this paper throughout the research process. His design of this course shaped my research and exposed me to an underexplored and fascinating body of research. I appreciate his ongoing support of all my research efforts.

\section{REFERENCES}

Hansell, William H. "Some Themes in the Jamaican Poetry of Claude McKay." Phylon: The Atlanta University Review of Race and Culture 40.2 (1979): 123-39. Web. 
Higman, B. W. Jamaican Food : History, Biology, Culture. Jamaica: University of the West Indies, 2008. Print.

James, Winston. "Becoming the People's Poet: Claude McKay's Jamaican Years, 1889-1912." Small Axe: A Caribbean Journal of Criticism 13 (2003): 17-45. Web.

James, Winston. “Jamaican Nationalism and Its Limits.” A Fierce Hatred of Injustice: Claude McKay's Jamaica and His Poetry of Rebellion. New York: Verso, 2001. 91-114. Web.

McKay, Claude, and Maxwell, William J. Complete Poems. Urbana: University of Illinois, 2004. American Poetry Recovery. Print.

Peppis, Paul. "Salvaging Dialect and Cultural Cross-Dressing in McKay's Constab Ballads." Twentieth Century Literature 59.1 (2013): 37-78. Web.

Rosenberg, Leah Reade. Nationalism and the Formation of Caribbean Literature (1st ed.). New York: Palgrave Macmillan, 2007. Web.

Tillery, Tyrone. Claude McKay : A Black Poet's Struggle for Identity. Amherst: University of Massachusetts, 1992. Print. 